\title{
Tax regulation of the Russian Federation health resorts as a sustainable development factor
}

\author{
Marina Levkevich ${ }^{1, *}$, Natalia Bryukhanova ${ }^{2}$, and Galina Astratova ${ }^{3,4}$ \\ ${ }^{1}$ Academy of Labor and Social Relations, 90, Lobachevky str., 119454, Moscow, Russia \\ ${ }^{2}$ Inter RAO - Procurement Management Center, LLC, 27, Bolshaya pirogovskaya str., 119435, Moscow, \\ Russia \\ ${ }^{3}$ Ural Federal University named after the first President of Russia B.N. Yeltsin, 13 b, Lenina Prospect, 620000, \\ Yekaterinburg, Russia \\ ${ }^{4}$ Ural Juridical Institute of MIA of Russia, 66, Korepina str., 620057, Yekaterinburg, Russia
}

\begin{abstract}
Ensuring the health of the population and promoting universal well-being is a priority goal for all mankind. It is confirmed by national projects and interstate programs in the field of sustainable development. A special role in the issue of universal health coverage is played by the services of health resort organizations (HRO). HRO play an important role in ensuring the sustainable development of the Russian industrial territories, contributing to the achievement of good health, well-being and economic activity of the population. The development of HRO in Russia faces a number of problems. One of the most ones is improving the tax policy in the health resort industry. Despite the relevance, this issue is very poorly studied. That is why it is necessary to use adequate taxation regulatory mechanisms. Analysis of the economic activity results of a number of HRO allowed concluding that most of them are unprofitable. The actual tax burden is much higher than recommended by the fiscal authorities. The purpose of the study was to analyze the tax regulation in the health resort sphere and to develop tax regulation methods that contribute to achieving the goal of sustainable development of the state in the field of health. The results obtained allow us to draw conclusions and propose some taxation methods in the health resort sector.
\end{abstract}

\section{Introduction}

Ensuring a healthy lifestyle and promoting universal well-being is one of the key goals of sustainable development of States until 2030, according to the UN Resolution [1]. These goals are closely intertwined with the national project of Russia "Healthcare" [2]. In particular, building a healthier society is based on the principle of universal health coverage, the provision of which is aimed at protecting the health of citizens. In the structure of health services to provide diagnostic services, outpatient care centers, hospitals, multi-center, sanatorium and SPA organizations, rehabilitation centers, health resort

\footnotetext{
*Corresponding author:1m137@mail.ru
} 
organizations, and others. $[3,4,5]$. A special role in the issue of universal coverage of health services play services of health resort organizations (HRO).

HRO are health care organizations that provide medical services aimed at restoring health and preventing morbidity among the population. The public administration sector conducts an active policy of promoting a healthy lifestyle of citizens, focusing on participation in recreational activities, including regular SPA treatment. Health resort organizations, including sanatoriums (for children, for children with parents, at al.), health resorts, health clinics, mud baths, balneological hospitals, etc., due to the social significance of the services provided, need state support and the creation of the most favorable conditions. HRO play an important role in ensuring the sustainable development of industrial areas, contributing to the achievement of one of the most important goals - good health and well-being of the population, not only forming the social well-being of society, but also supporting the economic activity of the population [3, 4, 5, and 6]. This is especially important for the Russian Federation.

However, currently the development of HRO in the Russian Federation faces a number of challenges, among which the most typical are problems related to infrastructure, imperfect legal system, social problems and economic problems. As G.A. Karpova with colleagues [7] quite rightly point out, in our opinion, economic problems are mainly only a natural consequence of the above-mentioned problems. One of such serious economic problems of the HRO development is the problem of the tax policy improving in the health resort sphere. Taxation is very important, because it can both stimulate and discourage the development of the SPA\& HRO sector, forming an environment for development, ensuring a balance of interests of all participants in tax relations. Moreover, tax reforms can also help to achieve sustainable development of the state [8].

At the same time, the analysis of the literature available to us shows that this issue, despite its relevance, is very poorly studied both in the theoretical, methodological and practical aspects. So, there are separate works of tax discrimination analysis in some HRO [9] and general problems of taxation in all industry [10].

However, for the effective performance of the HRO functions, it is necessary to use adequate regulatory mechanisms, such as taxation of health service producers.

In this regard, the purpose of the study was to analyze the tax regulation in the health resort sphere and to develop tax regulation methods that contribute to achieving the goal of sustainable development of the state in the field of health.

\section{Materials and methods}

The main research tools used in this work are system analysis. Methods of empirical research, principles of formal logic, synthesis, statistical, logical methods, as well as methods of comparison, generalization, and structuring are used to study theoretical and practical material.

\section{Results}

Tax regulation in the health resort sphere is a targeted impact of the public administration sector on service producers, carried out through the use of methods and tools of tax policy adapted to the specifics of their activities, aimed at achieving socially significant results $[11,12$, and 13].

Tax regulation is carried out by defining the basic elements of taxation, making changes in the size of tax rates, providing tax benefits and preferences, determining the composition of subjects and objects of taxation, the tax procedure, etc. 
As a rule, when implementing tax policy, the following levers are used as instruments of tax regulation $[11,12$, and 13$]$ :

- First, the total amount of taxation, most often defined by the terms "tax burden" or "tax load". To regulate the development of any segment of the economy in order to reduce the activity of economic entities, the tax burden is increased. Conversely, reducing the tax burden encourages development and increases the number of economic entities;

- Secondly, structural changes in the tax system, accompanied by adjustments to the main elements: tax rates, the introduction of new taxes or cancellation of existing ones, changes in the composition of tax benefits, etc.;

- Third, the possibility of applying alternative tax systems, for example, such as the simplified tax system, etc.

The chosen methods and tools of tax regulation directly depend on the regulatory objectives. It is necessary to clearly understand what exactly is such a goal in the health resort sphere. In our view, when it comes to socially significant services, the priority should be given to the objectives set out in the concept of sustainable development, namely, social well-being and universal health coverage $[1,6]$. Based on this, when implementing tax regulation by the public administration sector, the most favorable conditions are created for organizations of the health resort sphere.

Before we turn to the consideration of certain aspects of tax regulation, we will determine the dynamics of revenues to the budget of the Russian Federation of taxes and fees in related areas. It should be noted that it is not possible to analyze the tax contribution of the health resort sector, since official data are publicly available only in the context of enlarged groups, such as: "activities of hotels and other places for temporary residence" and "activities in the field of health and social services". In the diagram (Fig. 1) the main trends of tax revenues to the consolidated budget for 2015-2019 are reflected.

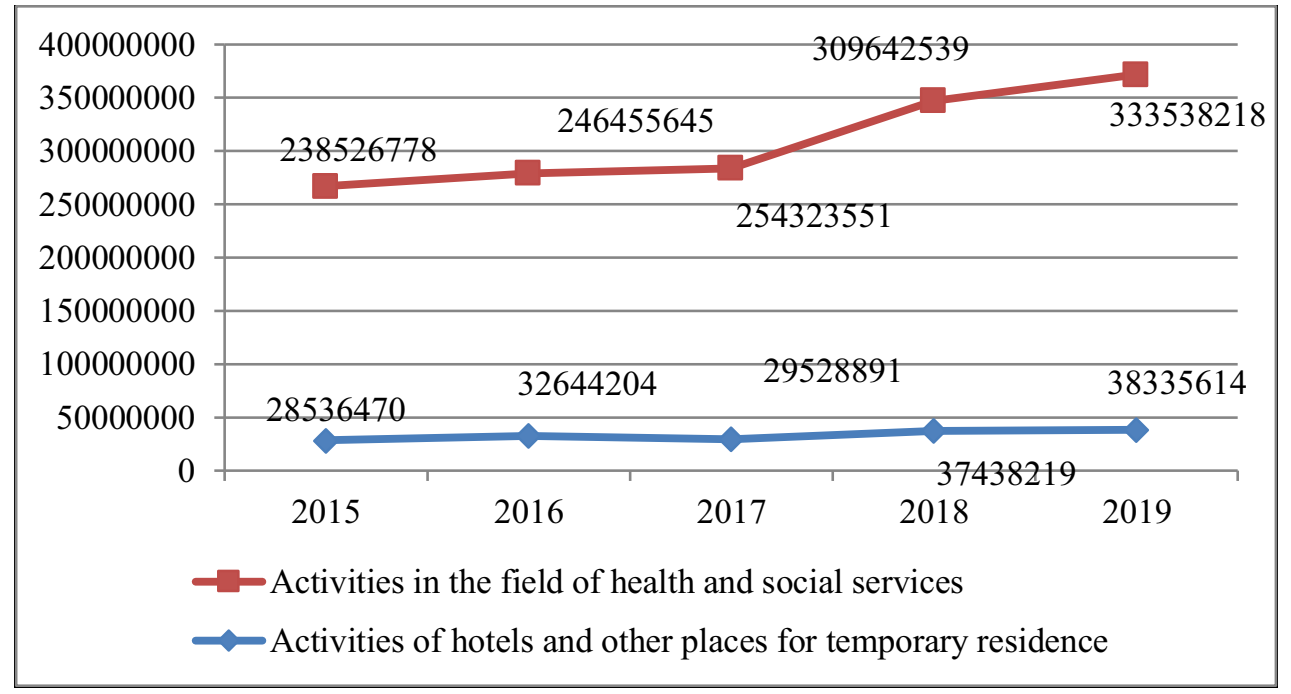

Fig. 1. Dynamics of receipt of payments of certain areas in the consolidated budget in 2015-2019, thousand rubles [14].

Over the period 2015-2019 group "activity of hotels and other places of temporary residence" has been an increase in the amount of payments on 9,799,144 thousand rubles, which corresponds to the growth rate 134,34 \%. In 2017, it registered a decrease in revenues for 3115313 thousand RUB compared to 2016. For the rest of the time intervals, there is a steady increase in payments. 
For the group "activities in the field of health and social services", an increase in payments of 95,011,440 thousand rubles was revealed in 2019 compared to 2015 . When comparing tax periods within the time interval of 2015-2019, we can note the trend of increasing payments from producers of health and social services. More detailed information is provided in Tables 1,2 .

Table 1. Deviations (absolute) in the receipts of payments of certain areas to the consolidated budget, thousand rubles.

\begin{tabular}{|l|c|c|c|c|}
\hline \multirow{2}{*}{ Individual areas } & \multicolumn{4}{|c|}{ Absolute change, (+,-) } \\
\cline { 2 - 5 } & $\begin{array}{c}\text { in 2016 } \\
\text { by 2015 }\end{array}$ & $\begin{array}{c}\text { in 2017 } \\
\text { by 2016 }\end{array}$ & $\begin{array}{c}\text { in 2018 } \\
\text { by 2017 }\end{array}$ & $\begin{array}{c}\text { in 2019 } \\
\text { by 2018 }\end{array}$ \\
\hline $\begin{array}{l}\text { Activities of hotels and } \\
\text { other places for temporary } \\
\text { residence }\end{array}$ & 4107734 & -3115313 & 7909328 & 897395 \\
\hline $\begin{array}{l}\text { Activities in the field of } \\
\text { health and social services }\end{array}$ & 7928867 & 7867906 & 55318988 & 23895679 \\
\hline
\end{tabular}

Table 2. Deviations (relative) in the receipts of payments of certain areas to the consolidated budget, thousand rubles.

\begin{tabular}{|l|c|c|c|c|}
\hline \multirow{2}{*}{ Individual areas } & \multicolumn{4}{|c|}{ Relative change, \% } \\
\cline { 2 - 5 } & $\begin{array}{c}\text { in 2016 } \\
\text { by 2015 }\end{array}$ & $\begin{array}{c}\text { in 2017 } \\
\text { by 2016 }\end{array}$ & $\begin{array}{c}\text { in 2018 } \\
\text { by 2017 }\end{array}$ & $\begin{array}{c}\text { in 2019 } \\
\text { by 2018 }\end{array}$ \\
\hline $\begin{array}{l}\text { Activities of hotels and } \\
\text { other places for temporary } \\
\text { residence }\end{array}$ & 114.39 & 90.46 & 126.79 & 102.40 \\
\hline $\begin{array}{l}\text { Activities in the field of } \\
\text { health and social services }\end{array}$ & 103.32 & 103.19 & 121.75 & 107.72 \\
\hline
\end{tabular}

In the diagram (Fig. 2) the contribution of the groups "activities of hotels and other temporary accommodation" and "activities in the field of health and social services" to the consolidated budget of the country is presented.

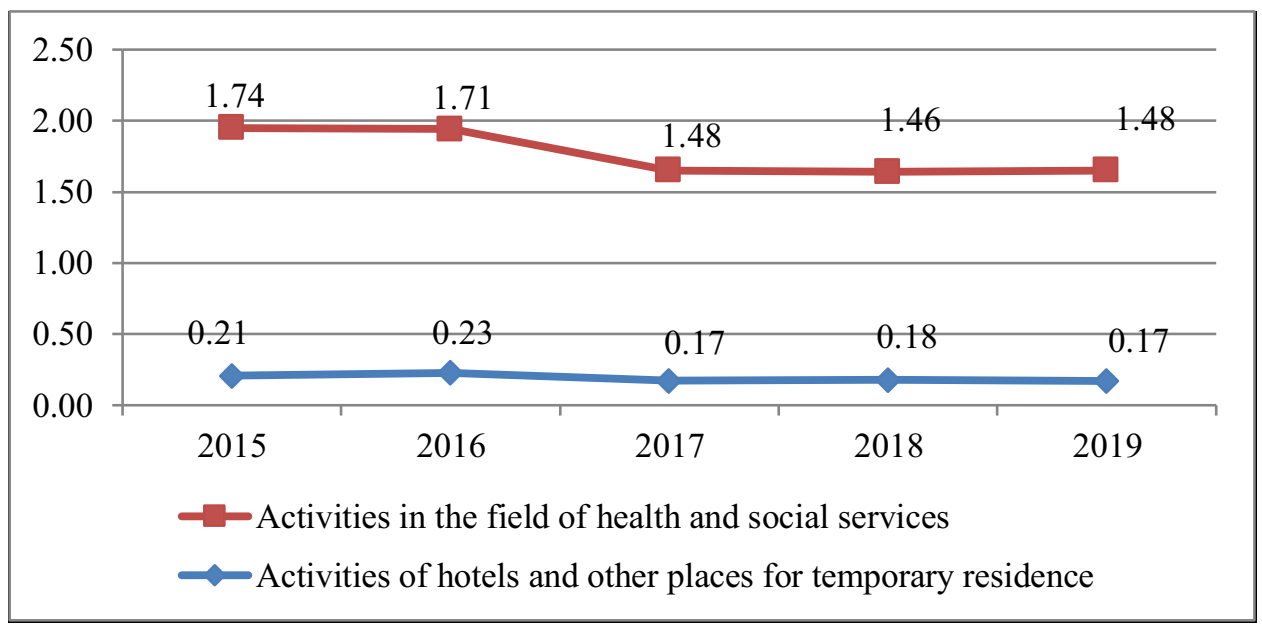

Fig. 2. The share of payments received by certain areas in the consolidated budget in $2015-2019, \%$ [14].

For both groups, there is a decrease in the share of the consolidated budget in 20152019. Against the background of an increase in the absolute value of income from each of the analyzed types of economic activity, we can say that other areas and industries are developing more dynamically. 
As for taxation itself, today the producers of health resort services are payers of the following taxes: corporate income tax, VAT, property tax, transport tax, personal income tax as a tax agent, insurance premiums, other taxes and fees. As for tax benefits, they apply exclusively to VAT. According to paragraph 8, point 3, Article 149 of the Tax Code of the Russian Federation [11], the services of health resort organizations issued with vouchers or courses that are forms of strict reporting are not subject to taxation .

We will conduct a study of the tax burden of producers of health resort services and compare it with the recommended level of the Federal Tax Service of the Russian Federation $[11,12,13]$. For this purpose, the data of accounting and tax accounting of 20 health resort organizations of the cities of Krasnodar Territory, such as Anapa, Gelendzhik, Novorossiysk, Sochi, Tuapse, will be used.

Analysis of the results of the HRO activities allows us to conclude that for the most part it is recognized as unprofitable. In order to identify the general trend in the profitability of the functioning of sanatorium organizations, we will analyze the results of the activities of some $20 \mathrm{HRO}$ in the Krasnodar Territory.

We will present the analytical data in the diagram (Fig. 3).

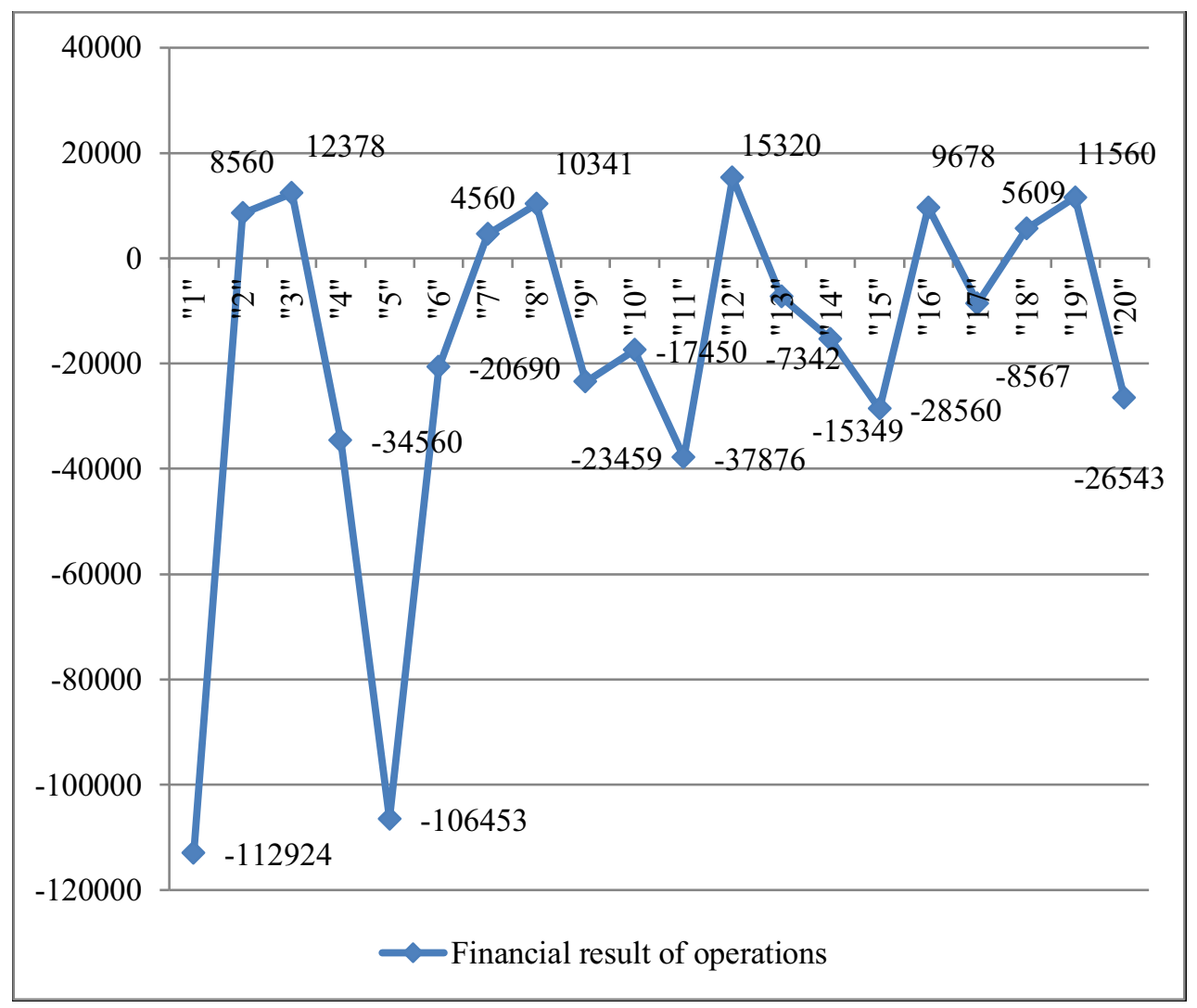

Fig. 3. Illustration of the financial performance of 20 health resort organizations in the Krasnodar Territory in 2020 (random selection).

According to the data shown in the diagram (Fig. 3), out of 20 health resort organizations (hereinafter referred to as HRO), only eight economic entities in 2020 have a positive financial result of their activities, i.e. profit. The maximum amount of profit received is 15,230 thousand rubles. The average profit per HRO was RUB 9,751 thousand. 12 business entities out of 20 ended the year with a loss. 
In order to analyze the impact of the tax burden on the financial result of the HRO activity, we will consider the taxation of health resort organizations in more detail.

We will present the tax burden of health resort organizations, detailing the tax accounting data of the HRO «1» (Table 3 ).

Table 3. Taxes and insurance premiums transferred to the budget of the HRO «1» for 2018-2020, RUB.

\begin{tabular}{|c|c|c|c|c|c|c|}
\hline \multirow{2}{*}{ Taxes } & \multicolumn{3}{|c|}{ Tax amounts, rub. } & \multicolumn{3}{c|}{ Absolute change, (+,-) } \\
\cline { 2 - 7 } & $\mathbf{2 0 1 8}$ & $\mathbf{2 0 1 9}$ & $\mathbf{2 0 2 0}$ & $\begin{array}{c}\text { in 2019 } \\
\text { by 2018 }\end{array}$ & $\begin{array}{c}\text { in } \\
\text { by 2019 }\end{array}$ & $\begin{array}{c}\text { in 2020 } \\
\mathbf{2 0 1 8}\end{array}$ \\
\hline $\begin{array}{c}\text { Insurance } \\
\text { premiums }\end{array}$ & 28173055 & 34204499 & 28183146 & 6031444 & -6021353 & 10091 \\
\hline $\begin{array}{c}\text { Personal } \\
\text { income tax }\end{array}$ & 12952595 & 15539006 & 13933846 & 2586411 & -1605160 & 981251 \\
\hline VAT & 837737 & 25706503 & 35679444 & 24868766 & 9972941 & 34841707 \\
\hline $\begin{array}{c}\text { Transport } \\
\text { tax }\end{array}$ & 20143 & 9139 & 9200 & -11004 & 61 & -10943 \\
\hline $\begin{array}{c}\text { Property } \\
\text { tax }\end{array}$ & 39867568 & 38829789 & 18595456 & -1037779 & -20234333 & -21272112 \\
\hline $\begin{array}{c}\text { Other } \\
\text { taxes and } \\
\text { fees }\end{array}$ & 149933 & 312467 & 59770 & 162534 & -252697 & -90163 \\
\hline Total & 82001031 & 114601403 & 96460862 & 32600372 & -18140541 & 14459831 \\
\hline
\end{tabular}

The diagram (Fig. 4) shows the dynamics that characterize the amount of taxes paid HRO «1».

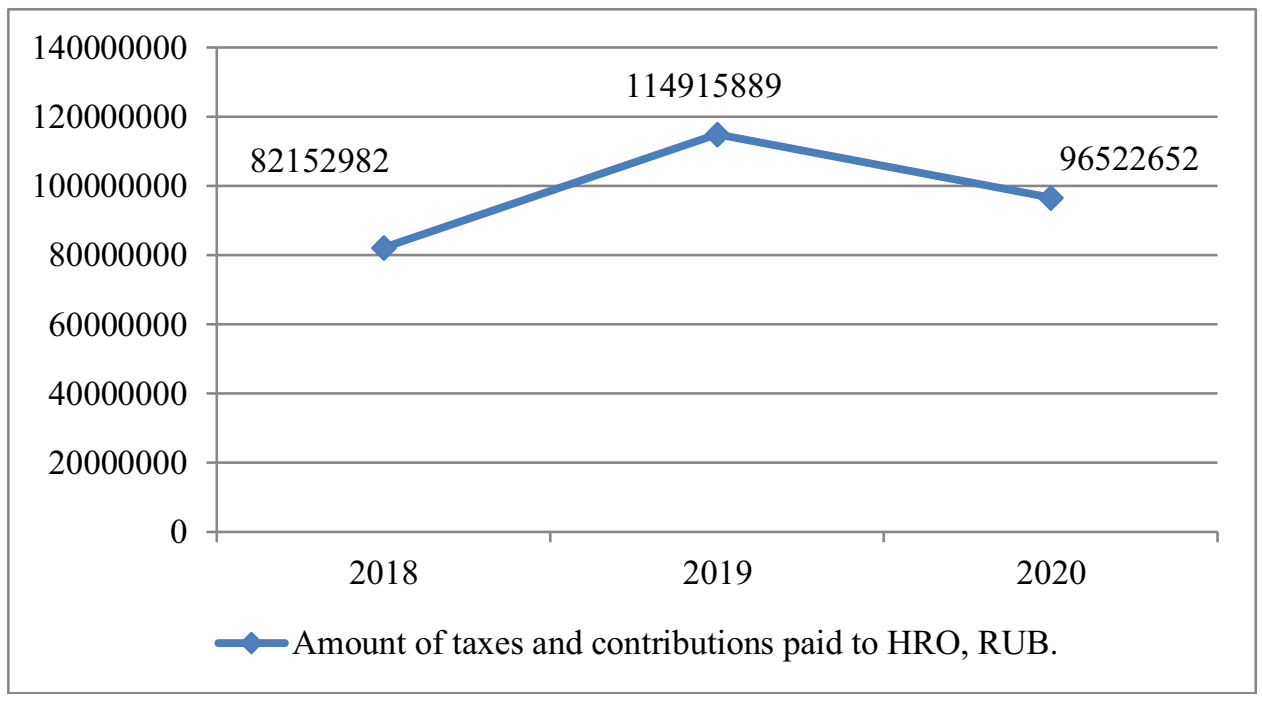

Fig. 4. The amount of taxes and contributions paid by HRO «1» to the budget and to extra-budgetary funds in 2018-2020, RUB.

The growth rates of taxes and fees are shown in Table 4. 
Table 4. Data on the relative changes in taxes and fees paid by HRO «1» for the period 2018-2020, $\%$.

\begin{tabular}{|c|c|c|c|}
\hline \multirow{2}{*}{ Taxes } & \multicolumn{3}{|c|}{ Relative change, \% } \\
\cline { 2 - 4 } & $\begin{array}{c}\text { in 2019 } \\
\text { by 2018 }\end{array}$ & $\begin{array}{c}\text { in } \\
\mathbf{2 0 2 0} \\
\text { by 2019 }\end{array}$ & $\begin{array}{c}\text { in 2020 } \\
\mathbf{2 0 1 8}\end{array}$ \\
\hline Insurance premiums & 121.41 & 82.40 & 100.04 \\
\hline Personal income tax & 119.97 & 89.67 & 107.58 \\
\hline VAT & 3068.56 & 138.80 & 4259.03 \\
\hline Transport tax & 45.37 & 100.67 & 45.67 \\
\hline Property tax & 97.40 & 47.89 & 46.64 \\
\hline Other taxes and fees & 208.40 & 19.13 & 39.86 \\
\hline Total & 139.76 & 84.17 & 117.63 \\
\hline
\end{tabular}

We will calculate the tax burden of the $\mathrm{HRO}$ «1» and present the data in Table 5.

Table 5. Calculation of the total tax burden HRO «1» for the perod 2018-2020.

\begin{tabular}{|c|c|c|c|}
\hline \multirow{2}{*}{ Taxes } & \multicolumn{3}{|c|}{ Amounts. rub. } \\
\cline { 2 - 4 } & $\mathbf{2 0 1 8}$ & $\mathbf{2 0 1 9}$ & $\mathbf{2 0 2 0}$ \\
\hline Personal income tax & 12952595 & 15539006 & 13933846 \\
\hline VAT & 837737 & 25706503 & 35679444 \\
\hline Transport tax & 20143 & 9139 & 9200 \\
\hline Property tax & 39867568 & 38829789 & 18595456 \\
\hline $\begin{array}{c}\text { The amount of taxes involved in the } \\
\text { calculation of the total tax burden. rub. }\end{array}$ & 149933 & 312467 & 59770 \\
\hline Revenue (without VAT). rub. & 24897976 & 80396904 & 68277716 \\
\hline Total tax burden. rub. $\%$ & $\mathbf{2 1 . 5 3}$ & 280561045 & 253965112 \\
\hline
\end{tabular}

The tax burden, which is practically synonymous with the concept of "tax load", can be defined as an absolute and relative value. Considering the tax burden as a relative value, it is possible to calculate the degree of diversion of funds from economic turnover to the fee of tax payments, which allows us to assess the impact of the amount of tax payments on the efficiency and profitability of the business.

It should be noted that there are numerous approaches to the calculation of the total tax burden (TTB), presented in various sources. When calculating, we will be guided by the Order of the Federal Tax Service of Russia [15], in which the TTB is defined as the ratio of the amount of taxes paid (according to tax reports) to revenue, which is reflected in the income statement (excluding VAT).

Important clarification:

- The amount of taxes includes personal income tax;

- The amount of taxes does not include insurance premiums;

- The calculation does not include VAT on imported goods and taxes paid as a tax agent (personal income tax is an exception).

In our opinion, the issue of including the personal income tax in the calculation of the TTB (the economic entity lists it as a tax agent) and not including insurance contributions to extra-budgetary funds that are transferred at its own expense is debatable. Nevertheless, using the methodology developed by the Federal Tax Service, the TTB is significant and amounts to about $26 \%$ (Fig. 5). 


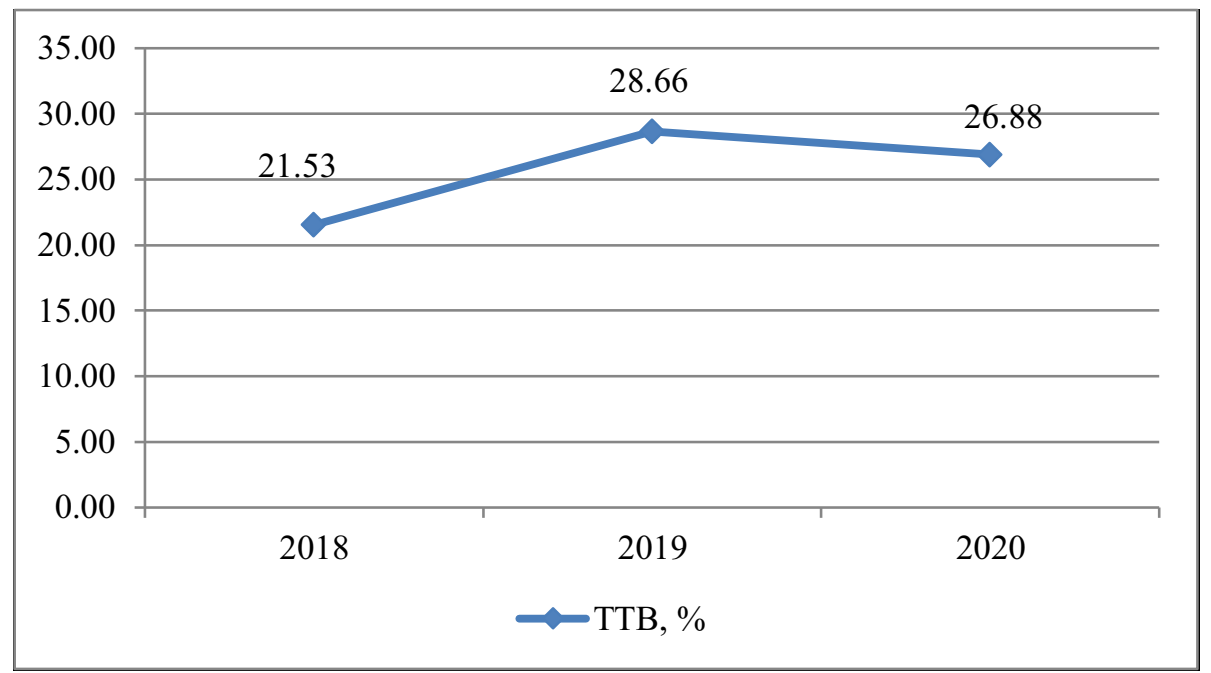

Fig. 5. The total tax burden (TTB) of health resort organizations for the period $2018-2020$ years, $\%$.

The tax burden is one of the evaluation criteria for the Federal Tax Service when making a decision on conducting an on-site tax audit. Every year, the Federal Tax Service of the Russian Federation updates data on the recommended level of the tax burden. As for the tax burden of the health resort organizations, such type of activity as "activities of sanatorium organizations" is not evaluated separately.

The Letter of the Federal Tax Service [16] indicates that in this case, it is necessary to take into account the level of the tax burden for similar industries. For example, in 2018 it was $11.0 \%$, in $2019-11.2 \%$.

Let's compare the recommended level of the tax burden with the actual level for the 20 HRO of the Krasnodar Territory participating in the study, and present it in the diagram (Fig. 6).

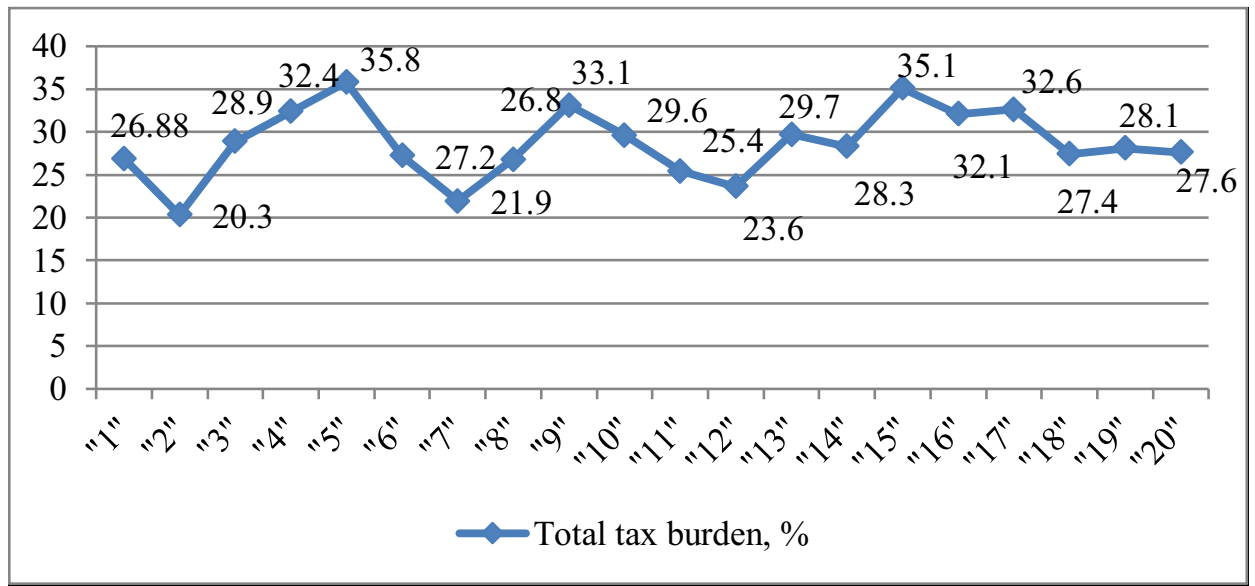

Fig. 6. Illustration of the tax burden of 20 health resort organizations in the Krasnodar Territory in 2020. (random selection).

From the diagram (Fig. 6) it can be seen that the tax burden of $20 \mathrm{HRO}$ is almost 3 times higher than the recommended level (the average tax burden was $28.64 \%$ ). 


\section{Discussion}

For the analyzed period of 2015-2019, the composition of taxes that are transferred to the budgets of various levels by health resort organizations remained the same. The largest changes affected personal income tax, the share of which increased in 2015 from $80.08 \%$ to $83.55 \%$ in the total amount of taxes (in absolute terms by $87,652,806$ thousand rubles). With regard to the corporate property tax, the following can be noted: its share decreased from $7.56 \%$ in 2015 to $6.1 \%$ in 2019 (in absolute terms by 2,31,455 thousand rubles). For the rest of the taxes, the fluctuations are insignificant.

The decrease in the amount of corporate property tax is due to the reduction in their number from 1,878 in 2015 to 1,777 in 2019 , which amounted to 101 organizations or a growth rate of $94.62 \%$ (Fig. 8).

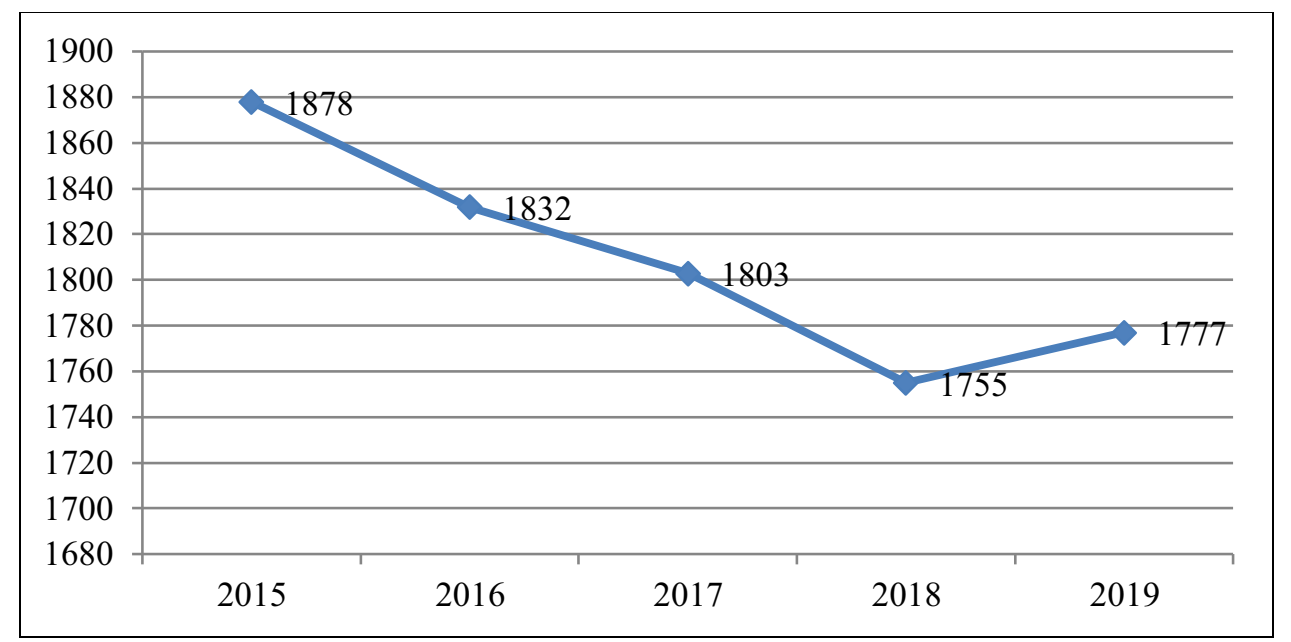

Fig. 7. Number of health resort organizations in Russia in 2015-2019, units [17].

In the period from 2015 to 2019 , the growth rate was:

- in 2016 compared to $2015-97.55 \%$;

- in 2017 compared to $2016-98.42 \%$;

- in 2018 compared to $2017-97.34 \%$;

- in 2019 compared to $2018-101.25 \%$.

It was in 2019 that the number of health resort organizations ceased to decline and there was an increase in 22 units, which, of course, is a positive trend that characterizes the interest in health services.

In this regard, information on the dynamics of the HRO paid services provision is of interest, which remains positive throughout the analyzed period (Fig. 9). 


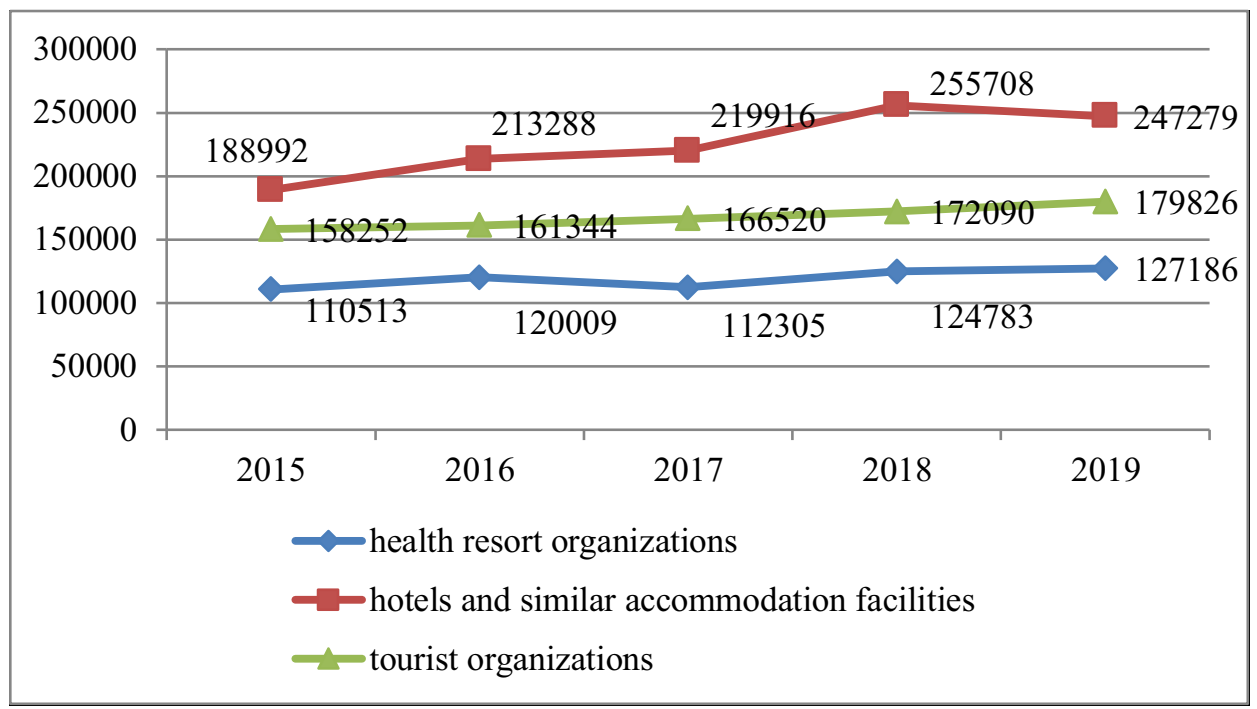

Fig. 8. Volumes of some types of paid services to the population in 2015-2019, thousand rubles [17].

In the positive dynamics of the growth of health resort organizations services, the exception is 2017 , in which the growth rate compared to 2016 was $93.58 \%$ (the volume of HRO services decreased from 120,009 million rubles to 112,305 million rubles).

In the remaining years, the following growth rates were recorded:

-in 2016 compared to $2015-108.59 \%$;

- in 2018 compared to $2017-111.11 \%$;

- in 2019 compared to $2018-101.93 \%$.

For the period 2015-2019, the volume of HRO services increased by 16,673 million rubles, the growth rate was $115.09 \%$. For comparison: tourist services increased by 21,574 million rubles with a growth rate of $113.63 \%$, hotel services and similar accommodation facilities amounted to 58,287 million rubles with a growth rate of $130.84 \%$.

The proportion of HRO services in the total volume of services (tourism, services, hotels and motels, resorts), the situation looks as follows (Fig. 10).

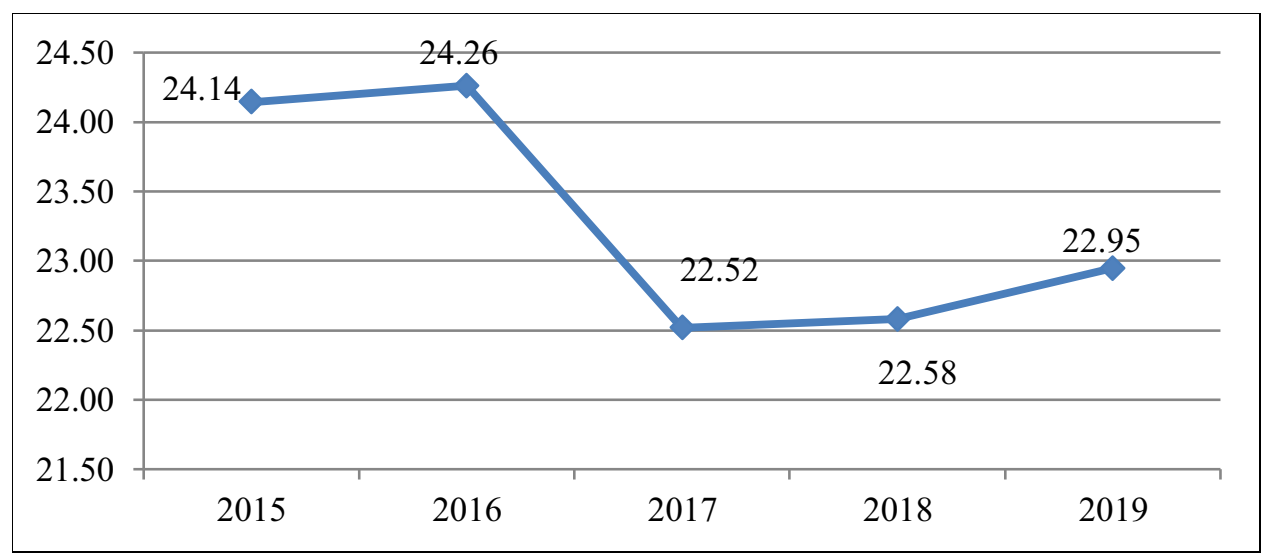

Fig. 9. The share of HROservices in the total volume of services (tourist services, hotel services and similar accommodation facilities, health resort organizations services) in 2015-2019, \% [17]. 
The largest share of HRO services was recorded in 2016 and amounted to $24.26 \%$. Then it began to decline, in 2019 it reached the level of $22.95 \%$.

The results of the analysis allow us to conclude that HRO sector needs a systematic approach to tax regulation.

Moreover, as said T.V. Yakovleva, Deputy Minister of Health of the Russian Federation, HRO is very important sector as it is a national treasure of Russia, the potential of which is important to develop and preserve for a long time [18]. Given the social importance of health resort organizations services, priorities should be set in relation to healthy lifestyles as a key priority for sustainable development, including regular health improvement, and disease prevention in HRO.

With this approach, we believe it is possible to talk about the need to form a special industry-specific tax regime and use it as a comprehensive regulator for the development of the health resort sector by creating the most-favored-nation conditions. In general, the special branch tax regime contains a system of benefits that are introduced for several taxes and fees for taxpayers providing HRO services.

In addition, it is necessary to adjust the tax rates for the tax regulation of the HRO sector, which will reduce the tax burden, allowing to free up funds for development. For example, in relation to corporate income tax for educational and medical organizations, the use of a zero rate (Article 284.1 of the Tax Code of the Russian Federation) [11] is provided if certain conditions are met. However, the lawmakers did not classify the activities related to HRO treatment as medical. It turns out that the HRO have no grounds for applying a zero rate.

Unfortunately, there are quite a few such unjustified decisions of the legislators concerning the taxation of producers of socially significant services. It is necessary to make a conscious choice of tax regulation tools that correspond to the vector of social policy implementation in Russia.

\section{Conclusion}

The tax policy implemented in the health resort sector of the Russian Federation is directly related to State social policy. The emphasis placed by the public administration sector in relation to the producers of health services determines the tools of tax regulation. Definitely, to our mind, creating a platform for the sustainable development of health resorts, bringing the demand for their services among the population at least to the Soviet level requires reducing tax expectations when replenishing budgets at various levels.

We consider, that the priority purpose of the taxation of the HRO shouldn't be only the replenishment of the budget. The main objectives of the health resort organisations activities are to support the health of citizens, ensuring their economic activity and working capacity. The successful solution of these tasks ensures the sustainable development of industrial areas, where there is traditionally a high level of morbidity due to the environmental situation and occupational diseases. Providing opportunities for the development of the material and technical base of HRO by freeing up funds from reducing the tax burden is a contribution to the future, to the health of the nation.

Another issue that does not lose its relevance is the question of the territorial distribution of health resort organizations. Traditionally HRO are concentrated in the Southern Federal District (about $23 \%$ ), followed by the Volga Federal District (located about $20 \%$ of HRO) and North Caucasus Federal District (approximately $16 \%$ ). The share of Russian industrial territories, such as: the Ural Federal District, the Siberian Federal District, and the Far Eastern Federal District compris about $8.3 \%, 12 \%$, and 2.4\%, respectively. It is not only the concentration of health resorts, but also the level of accessibility of HRO services for the population with low incomes, who live in difficult 
climatic and environmental conditions. Restoring the number of health resort organizations, creating favorable conditions for the provision of socially significant services, including through tax regulation, will contribute to achieving the goals of sustainable development of these territories in Russia.

\section{References}

1. Sustainable Development Goals https://www.un.org/sustainabledevelopment/ru/sustainable-development-goals/

(2019)

2. Passport of the national project "Healthcare" (approved by the Presidium of the Presidential Council for Strategic Development and National Projects, Protocol No. 16 of December 24) (2018) https://base.garant.ru/72185920/

3. J.R. Vest, S.J. Grannis, D.P. Haut, P.K. Halverson, N. Menachemi, International Journal of Medical Information 107, 101-106 (2019) DOI: https://doi.org/10.1016/j.ijmedinf.2017.09.008

4. S.K. Luneva, P.P. Pogorelskiy, Technical and technological problems of the service 4(50), 92-98 (2019)

5. L.I. Vasiltsova, Municipal health care: socio-economic aspects of transformation (USUE Publishing House, Yekaterinburg, 2004)

6. Quality of life: yesterday, today, tomorrow. Actual problems of Russia's accession to the WTO. Scientific monograph (Publishing house of the GC "Positive Strategy", Yekaterinburg, 2012)

7. G.A. Karpova, Yu.V. Dolmatenia, V.A. Tkachev, Services in Russia and Abroad 12(1), 52-63 (2018) DOI: 10.24411/1995-042X-2018-10105

8. N. Mathieu-Bolh, Resource and Energy Economics 50, 135-163 (2017) DOI: https://doi.org/10.1016/j.reseneeco.2017.06.004

9. M.E. Shkvarsky, Scientific bulletin: finance, banks, investments 1, 29-34 (2011)

10. A.J. Yakovleva, Economics and Society 1 (44), 987-989 (2018)

11. Tax code of the Russian Federation. (1998). July 31, $1998 \mathrm{~N}$ 146-FZ, http://www.consultant.ru/document/cons_doc_LAW_19671/

12. N.V. Bryukhanova, M. M. Levkevich, O.A. Levshukova, Bulletin of the Academy of Knowledge 6(41), 341-343 (2020) https://cyberleninka.ru/article/n/nalogooblozheniepriobreteniya-sanatorno-kurortnyh-putevok-dlya-sotrudnikov

13. M.M. Levkevich, E.P. Novikova, Siberian Financial School 4(123), 119-123 (2017)

14. Official website of the Federal Tax Service of Russia, https://www.nalog.ru/rn66/

15. Order of the Federal Tax Service of Russia of 30.05.2007 N MM-3-06/333@ "On Approval of the Concept of the System for Planning On-site Tax Audits" (2012)

16. Letter of the Federal Tax Service dated August22 GD-3-1/5806@(2018)

17. Official website of the Federal State Statistics Service, https://rosstat.gov.ru

18. T.V. Yakovleva, The health resort sector is a national treasure of Russia, the potential of which is important to develop and preserve, http://ktovmedicine.ru/files/issues/2_2017.pdf 